\title{
Stem cell-derived tissue- associated regulatory T cells ameliorate the development of autoimmune arthritis
}

\author{
Mohammad Haque*, Kristin Fino, Jianxun Song \\ From 30th Annual Meeting and Associated Programs of the Society for Immunotherapy of Cancer (SITC 2015) \\ National Harbor, MD, USA. 4-8 November 2015
}

\section{Background}

Embryonic stem cells have the ability to grow indefinitely while maintaining pluripotency. Under the right circumstance, pluripotent stem cells (PSC) can produce almost all of the cells in the body including regulatory $\mathrm{T}$ cell $\left(\mathrm{T}_{\text {regs }}\right) . \mathrm{T}_{\text {regs }}$ are essential for normal immune surveillance systems, and their dysfunction leads to the development of diseases, such as autoimmune disorders. PSC are a potential renewable source of healthy $\mathrm{T}_{\text {regs }}$, which could treat a wide array of autoimmune disorders. However, the right circumstances for the development of antigen (Ag)specific $\mathrm{T}_{\text {regs }}$ from PSC (i.e., PSC- $\mathrm{T}_{\text {regs }}$ ) has not been well defined. So the purpose of this study is to develop antigenspecific $T_{\text {regs }}$ from pluripotent stem cells for treatment of Ag-induced arthritis (AIA) in mice.

\section{Methods}

In this study mouse iPS cells were transduced with FoxP3 and ovalbumin-specific TCR (OTII). iPS cells were driven toward $\mathrm{T}$ lymphocyte lineage by co-culture on OP9 cells expressing delta-like (DL1), a Notch ligand. The combination of Notch signaling, FoxP3, and TCR drove iPS cell to differentiation into Ag-specific $\mathrm{T}_{\text {regs. }}$. In vitro generated $\mathrm{T}_{\text {regs }}$ were adoptively transferred into AIA mice.

\section{Results}

Our results showed that TCR transduced iPS cells differentiated into $\mathrm{T}_{\text {regs }}$ and express CD3, TCR $\beta$, CD4, CD8, CD25, CTLA4 in vitro. Adoptive transfer of such $\mathrm{T}_{\text {regs }}$ dramatically suppressed autoimmunity in a wellestablished AIA model, including the inflammation, joint destruction, cartilage prostaglandin depletion, osteoclast activity, and Th17 production.

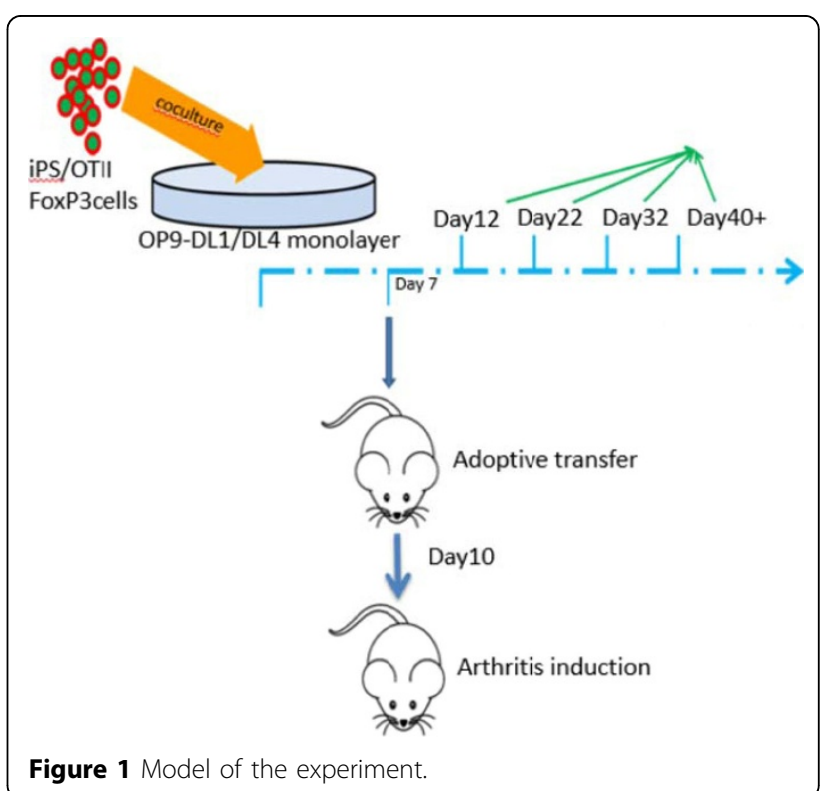

Published: 4 November 2015

doi:10.1186/2051-1426-3-S2-P21

Cite this article as: Haque et al:: Stem cell-derived tissue- associated regulatory $\mathrm{T}$ cells ameliorate the development of autoimmune arthritis. Journal for ImmunoTherapy of Cancer 2015 3(Suppl 2):P21.

Pennsylvania State University College of Medicine, Hershey, PA, USA 


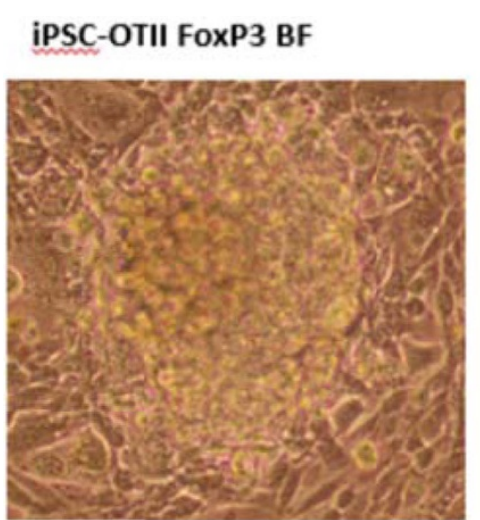

iPSC-OTII FoxP3 DsRed

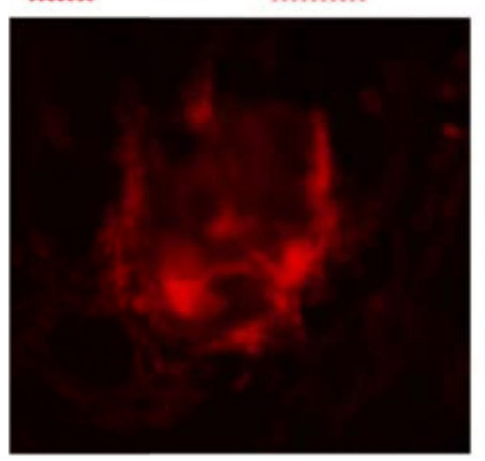

Figure 2 Retroviral transduction result.

\section{iPSC-OTII FoxP3 GFP}

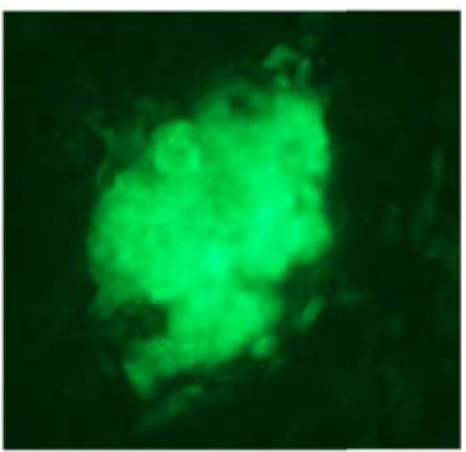

iPSC-OTII FoxP3 overlay

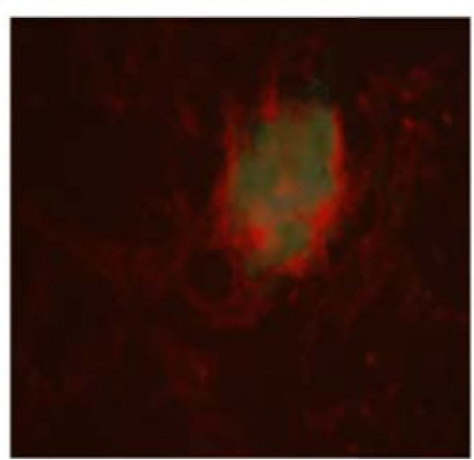

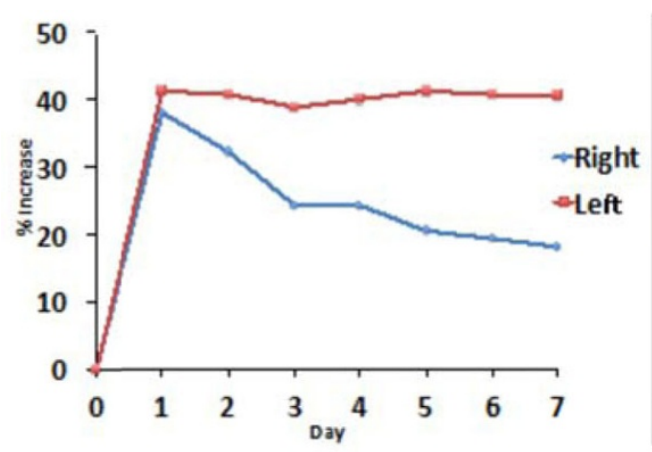
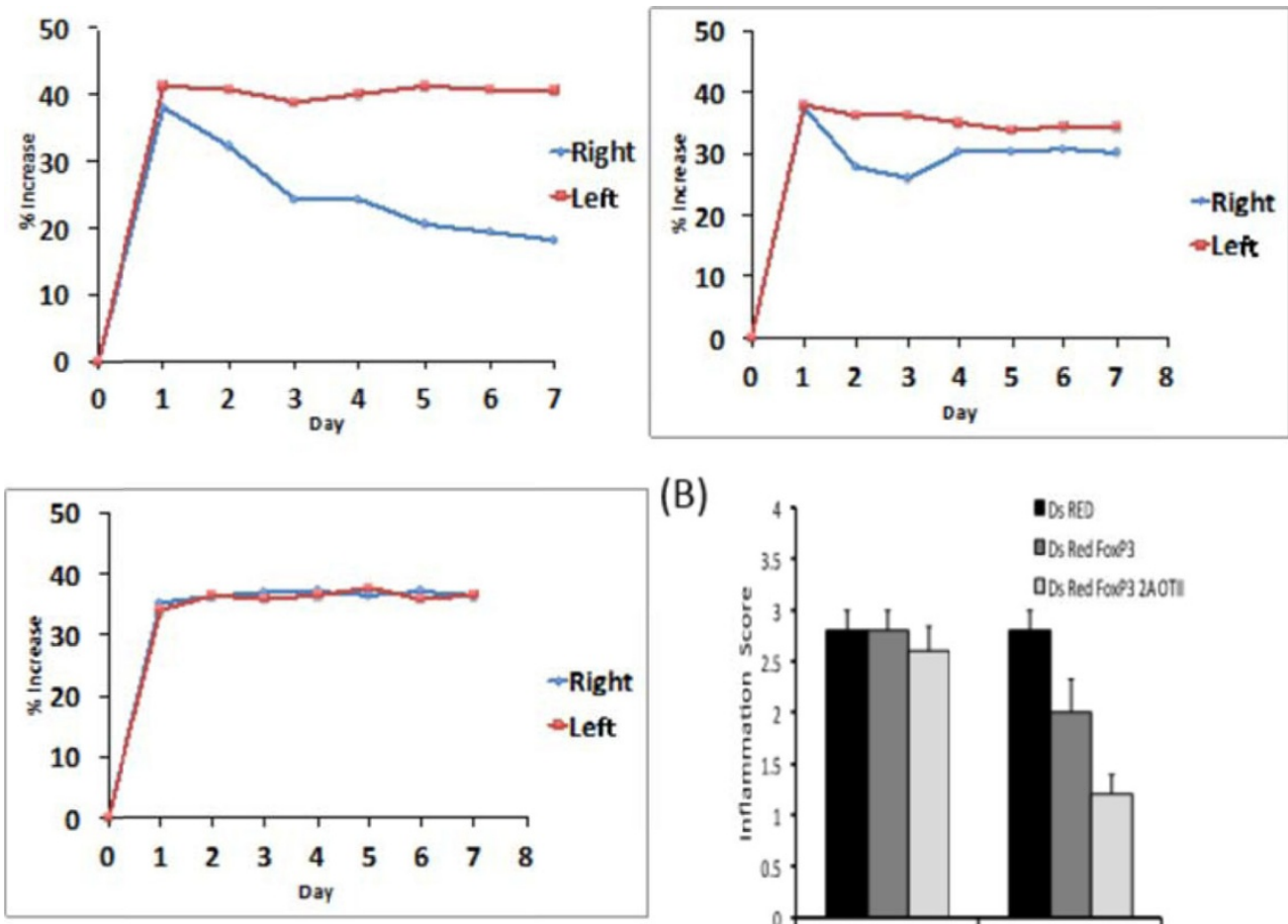

(B)

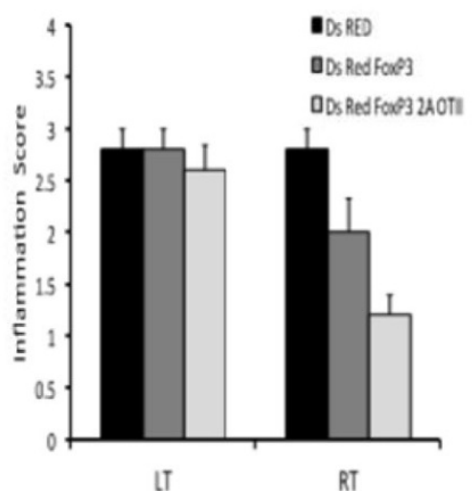

Figure 3 Arthritis development was reduced in adoptively transferred mice. 

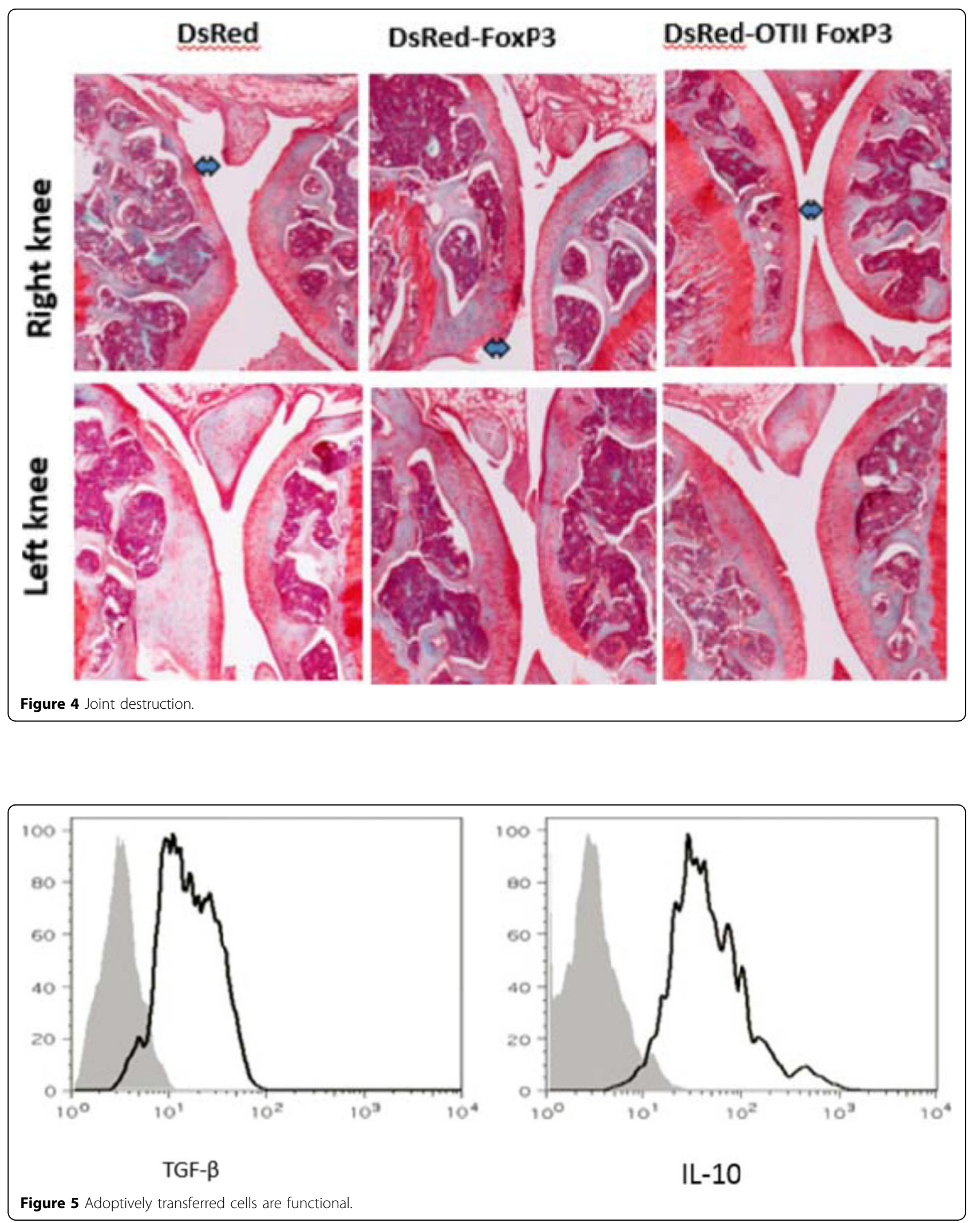


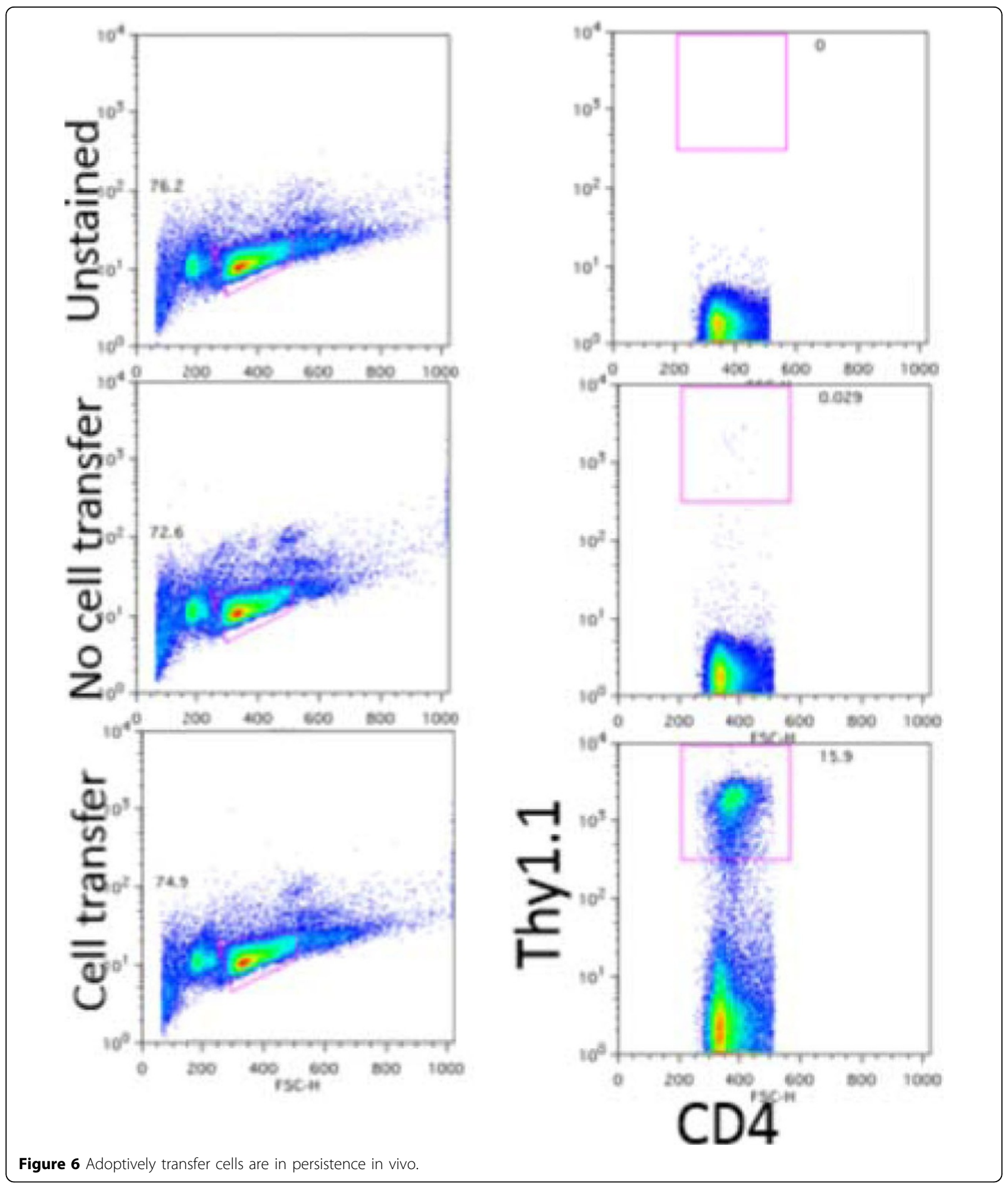

